\title{
Are marine protected areas a red herring or fisheries panacea? ${ }^{1}$
}

\author{
Michel J. Kaiser
}

\begin{abstract}
Chronic failures in marine fisheries management have led some to suggest that marine protected areas (MPAs) are the solution to achieve sustainable fisheries. While such systems work for certain habitat-specific and nonmobile species, their utility for highly mobile stocks is questionable. Often the debate among proponents and critics of MPAs is confused by a lack of appreciation of the goals and objectives of such systems. The current consideration of MPAs as the basis of future fisheries management is a symptom of, and not the singular solution to, the problem of inappropriate implementation of fishing effort controls. The latter will provide greater overall conservation benefits if properly applied. Any future use of MPAs as an effective tool to achieve sustainable fisheries management in temperate systems should be treated as a large-scale, rigorously designed experiment to ensure that the outcome of using MPAs is interpreted correctly and not discredited for false reasons.
\end{abstract}

Résumé : Les échecs répétés qui se produisent dans l'aménagement des pêches marines ont incité certains à avancer que les zones de protection marine (MPA) sont la solution pour l'obtention de pêches durables. Bien que ces systèmes fonctionnent pour certaines espèces sédentaires à habitat bien défini, leur utilité chez les stocks très mobiles peut être mise en doute. Les débats entre les partisans et les critiques des MPA sont souvent obscurcis parce que les buts et les objectifs de ces systèmes sont mal compris. L'évaluation des MPA comme bases d'un aménagement des pêches futures est un symptôme de l'application inadéquate des contrôles des efforts de pêche, plutôt que la solution parfaite au problème. Lorsqu'ils sont bien exercés, ces contrôles sont, dans l'ensemble, plus bénéfiques pour la conservation. Toute utilisation future des MPA comme outil efficace pour mettre en place un aménagement durable des pêches dans les systèmes tempérés devrait être vue comme une expérience à grande échelle et à planification rigoureuse, afin de s'assurer que les résultats de l'utilisation des MPA soient interprétés correctement et ne soient pas discrédités pour les mauvaises raisons.

[Traduit par la Rédaction]

Marine protected areas (MPAs) have been heralded as the saviour of global fisheries by some conservationists, fishers, and managers and are seen as the solution to the perceived failures of current management methods. The potential benefits of excluding fishing activity from parts of the sea is an easy concept for nonspecialists to grasp, making MPAs an alluring alternative to the complex array of current management tools (Roberts et al. 2001; Gell and Roberts 2003). Here, I argue that while MPAs can and have been used with success in certain locations for particular species (Gell and Roberts 2003; Roberts et al. 2005), they are not the cure-all

Received 10 May 2004. Accepted 31 December 2004.

Published on the NRC Research Press Web site at

http://cjfas.nrc.ca on 31 May 2005.

J18127

M.J. Kaiser. ${ }^{2,3}$ Marine Policy Center, Woods Hole Oceanographic Institute, Woods Hole, MA02543, USA.

${ }^{1}$ Contribution No. 11271 of the Marine Policy Center, Woods Hole Oceanographic Institute.

${ }^{2}$ Corresponding author (e-mail: michel.kaiser@bangor.ac.uk).

${ }^{3}$ Present address: School of Ocean Sciences, University of Wales-Bangor, Menai Bridge, Anglesey, LL59 5AB, UK. that some purport, and the scientific evidence chosen to support such conclusions on occasion has been drawn from those studies that demonstrate a positive outcome of MPA implementation (Halpern 2003; Zeller and Russ 2004). Needless to say, it may be equally important to understand better those circumstances when the use of MPAs has not been successful, as such instances provide useful metadata. In areas where highly mobile species are the target of the fishery, assessment of the full potential of MPAs as management tools are confounded by factors such as previous and concurrent fishing history, changes in size-at-age, community structure, genetic bottlenecks, stock collapse, and Allee effects (Frank et al. 2000; Willis et al. 2003a). Furthermore, the successful implementation of MPAs requires a crossdisciplinary approach that is far more complex than the biological conservation goals originally envisaged (Agardy et al. 2003; Ray 2004).

Much of the confusion surrounding the use of MPAs has stemmed from their intended objectives. The purpose of MPAs to conserve habitat and biodiversity of nontarget species is not necessarily consistent with the maintenance of sustainable fish stocks, although it is clear that in some cases these two goals can be met to some degree by the implemen- 
tation of an MPA. The scientific community is split regarding the efficacy of the unilateral use of MPAs to achieve sustainable exploitation of fish and shellfish stocks (Steele and Hoagland 2003, 2004; Zeller and Russ 2004). The appropriate and rigorous use of fishing effort controls that consider natural, long-term fluctuations in fish populations should achieve sustainable management. However, advocates of MPAs counter that the current severe decline in fish stocks has eliminated the potential for population increase even under favourable environmental conditions (Zeller and Russ 2004).

The wider ecosystem effects of fishing are cited as being incompatible with the aim of sustainable harvesting (Gell and Roberts 2003). Harvesting of fish from the seabed and the collateral damage that occurs from this has been compared with the clear-cutting of forests to catch deer (Watling and Norse 1998). These viewpoints typically lead to the conclusion that the only way to achieve sustainable use of fisheries is to exclude fishing activities from "large" areas of the ocean (Watling and Norse 1998). However, the implementation of appropriate MPAs is fraught with ecological, economic, and social problems that tend to be overlooked (Agardy et al. 2003). Although some of these problems are shared with current effort control systems (Hilborn et al. 2004), MPAs have a greater potential to exclude access by some fishers according to their geographic location. Worse still, MPAs have the potential to displace current fishing activities and thereby cause wider ecological damage to previously undisturbed and perhaps unknown, critical seabed habitats (i.e., essential fish habitat). However, there are circumstances when the benefits of using spatial effort control measures will offset some of the negative ecological effects of the displacement of fishing activities to alternative areas. Such examples would include the use of temporary closed areas to prevent fishing on spawning aggregations, on nursery areas, or at migration bottlenecks.

Most reviews of the ecological effects of MPAs draw on case studies in which fish biomass increased within areas from which fishing was excluded (Roberts et al. 2001; Gell and Roberts 2003; Halpern 2003). In general, these case studies focused on habitat-specific systems (e.g., coral or rock reefs) that are relatively small in scale $\left(<500 \mathrm{~km}^{2}\right.$; Halpern 2003). These systems are easier to protect from the effects of fishing, as the target species usually remain in close proximity to a well-delineated habitat (Russ and Alcala 1996; Willis et al. 2003b). Fishers that prosecute these systems usually live within kilometres of the specific habitat and depend upon it for a considerable proportion of their diet or income (Jennings et al. 1996; Blyth et al. 2002). Hence, their motivation to participate in MPAs is much greater compared with those who fish across areas of tens of thousands of square kilometres and who compete against fishers with whom they have little or no social contact.

A recent meta-analysis of MPAs reported general, positive biological effects that were most usually expressed as an increase in biomass within the reserve of both target and nontarget species (Halpern 2003). Interestingly, no relationship was found between the spatial extent of the MPA and the magnitude of the change in biomass or abundance of the protected target species' population (Halpern 2003). While it might be tempting to conclude that an MPA of any size would provide conservation benefits, even if only at a local scale, this holds true for only the majority of studies on which this meta-analysis was based: coral or temperate rock reefs. These conclusions are not valid for many of the commercially important, temperate fish species that are widespread across a variety of habitats, exhibit entirely different behaviours between sea basins, and may move considerable distances within a year (Metcalfe and Arnold 1997; Horwood et al. 1998; Horwood 2000). For these species, the critical and most demanding issue relating to the design of appropriate MPAs is the scale of the area required to achieve effective protection and stock enhancement of highly mobile fish stocks. Recent estimates indicate that a mean area equivalent to approximately $32 \%$ (range $10 \%-$ $65 \%$ ) of the area available for fishing would require protection (Gell and Roberts 2003). Note that these figures are once again based largely on studies of fish species with strong habitat-specific associations. However, for wideranging species such as Atlantic cod (Gadus morhua), calculations indicate that excluding fishing from an area as large as $25 \%$ of the North Sea would have a negligible effect on their spawning stock biomass (Horwood 2000). Given the multispecies nature of most temperate fisheries, the different MPA requirements of each species would add yet another layer of management complexity.

What would the composite map of species-specific MPAs look like and could they be implemented? These important questions are yet to be addressed; indeed, little if any consideration is given to the likely social and economic consequences for the inevitably reduced number of fishers in the system. With fishing excluded from large areas of the sea, a negotiated placement of MPAs to take into account useable fishing grounds that are accessible to all remaining participants would seem hopeful at best. In regions of the world where total control of exclusive economic zones is exercised out to 200 nautical miles, the placement of MPAs can be imposed through legislation. However, such simple solutions are not likely to be found in more complex systems, such as Europe, where multiple nations share access to the same resources. Even if such systems can be implemented, fishers can expect to wait decades before signs of stock recovery for certain stocks occur (Hutchings 2000; Steele and Beet 2003). Steele and Beet (2003) make the telling observation that the initial stages of MPA implementation would be doubly painful as fishers are deprived access to traditional fishing grounds and forced into less favourable fishing areas. This is further compounded by the added reductions in fishing effort (Zeller and Russ 2004). Furthermore, in the initial stages after MPA implementation, benthic production in the newly protected areas is likely to be low as it enters a phase of recovery once fishing disturbance has been removed, while those areas newly affected by displaced demersal effort will experience a severe decline in production varying according to habitat type (Jennings et al. 2001; Dinmore et al. 2003; J. Hiddink, School of Ocean Sciences, University of Wales-Bangor, Menai Bridge, Anglesey LL59 5AB, UK, unpublished data).

Given the unknown social and variable predicted economic consequences of a switch to management based on MPAs (Sanchiro and Wilen 2001), one has to ask what is supposedly wrong with current fishery management tech- 
Fig. 1. The relative fishing effort (sightings of fishing vessels per $100 \mathrm{~h}$ of overflight time) by bottom-fishing fleets in the Irish Sea, UK (inset box) that target sea scallops (Pecten maximus), demersal fishes, and Nephrops norvegicus (a type of burrowing crustacean). Data are from enforcement agency direct observations from light aircraft that overfly these areas on a regular basis. For each vessel sighting, the position, name, type, and activity of each vessel are noted. The data extend back to 1985 and have been aggregated into 5-year bins for ease of comparison and are expressed as sightings per unit effort of overflight (SPUE) (a) 1985-1989, (b) 1990-1994, (c) 1995-1999.
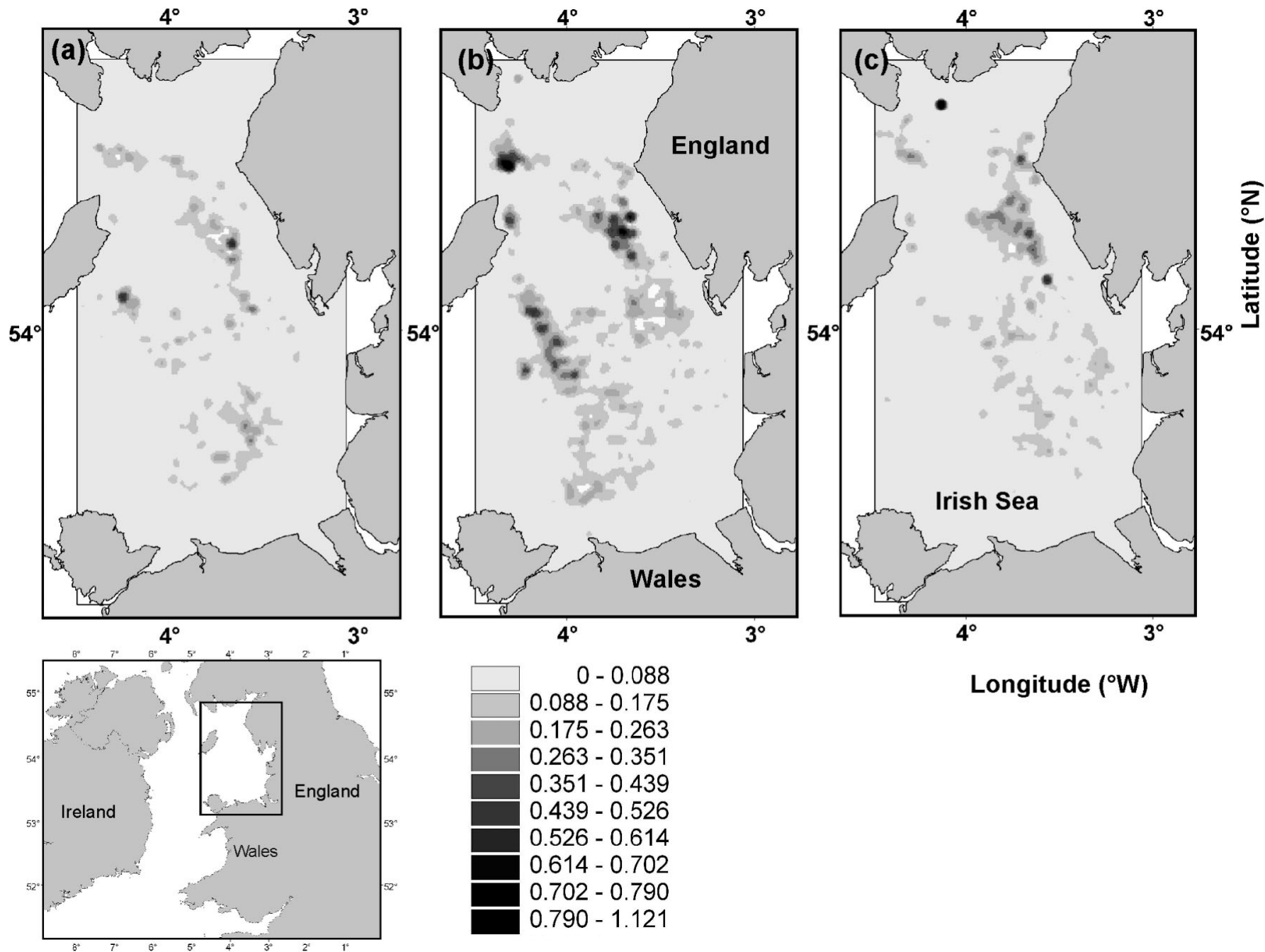

niques? I would argue that for many temperate species there is nothing fundamentally wrong with either the methodology of stock assessment or the available effort controls (e.g., days at sea) used in conjunction with catch controls, such as total allowable catches and individual transferable quotas. Indeed, when fishing effort control has been implemented effectively, fisheries have been managed successfully (e.g., the Western Australian rock lobster (Palinurus cygnus), New Zealand hoki (Macruronus novaezealandiae), Alaska salmon (Oncorhynchus spp.), and the Thames herring (Clupea harengus) fisheries, all of which have achieved Marine Stewardship Council certification as sustainable fisheries).

So why have other fisheries failed so dismally? Current fisheries management depends on annual forecasts of recruitment and catches that incorporate significant uncertainty. The political need to appease a desperate fishing industry has tended to push management decisions towards, and often beyond, the upper confidence limits for future al- lowable catches (Hutchings and Myers 1995). Such behaviour is not surprising given the typical short life-span of the average government, for whom the shadow of the future does not apply (Hart 1998). Do proponents of MPAs believe that scientific debate and uncertainty over the precise size, position, and configuration of MPAs will not provide the very same pathway to politically compromised management? If we ultimately move to a management system that is underpinned by a system of MPAs, we will still have to set a figure of how much and where. As soon as such figures are set, they will be vulnerable to erosion by a system of political negotiation. Given the effort that will be required to implement these systems, there is likely to be considerable resistance to alter their configuration should we decide at some point in the future that management objectives or large-scale environmental changes dictate their reconfiguration.

Furthermore, it is often stated that we require a portfolio of both MPAs and effort reduction to achieve sustainable use 
of fish stocks (Zeller and Russ 2004). If the latter is a prerequisite for the successful implementation of the former, the prognosis does not look too promising. If fishers are displaced by the imposition of an MPA from favoured fishing grounds into areas where catch rates of legal-sized target species are lower, the use of quota management is likely to result in a considerable increase in bycatch as fishers work harder (spend more time fishing at sea) to land the same quota. If the use of MPAs is to be successful, we first need to achieve effective fishing effort control. The failure or success of the use of an MPA as a fishery management tool (note the use of an MPA to protect specific habitat is excluded in this context) is inextricably linked to effective fishing effort control in the surrounding waters. As a result, there is a real risk that inadequately designed MPAs instigated without effective parallel effort control will be perceived by the industry and the wider public as failures and their utility discredited.

So far, our focus has been directed almost entirely on the fish and their biology. We have sought to control the activities of a predator, mankind, without devoting an equal effort to understanding the dynamics of a predator that operates in a system with imperfect knowledge about the distribution of the prey and the habitat in which they hunt them. Fishers sample the fish population and record their reward rate in space and time (Gillis and Peterman 1998). Nets are towed over areas of the seabed about which knowledge is known at a coarse scale. Charts with seabed features are not based on metre-accurate remote sensing as is possible on the land, but on sample points located tens or even hundreds of kilometres apart. What lies in between is uncertain. Even using echo-sounders, the instantaneous knowledge relayed to the wheelhouse of a fishing vessel provides information of only a few metres of the seabed directly beneath the hull and tells one nothing about the $20 \mathrm{~m}$ of seabed on either side that are about to be swept by the following fishing net. Thus every new exploratory tow using a bottom-towed fishing gear is potentially hazardous.

When fish stocks are healthy, fishers are most likely to repeatedly return to locations that they know from past experience to yield economically rewarding catches with a minimum risk to gear and vessel safety and avoid excessive competition with other fishers (Gillis and Peterman 1998; Holland and Sutinen 2000; Jin et al. 2002). As stocks decline and more fishing effort is required to maintain the same catch, fishers are forced to explore new areas where knowledge of the seabed and catch is uncertain. Evidence for this behaviour comes from vessel-monitoring systems and direct observations that demonstrate that fishing effort is highly aggregated and is only homogeneous at a scale of $1 \mathrm{~km}^{2}$ (Rijnsdorp et al. 1998). It is clear that large areas of the seabed remain unfished, while other areas receive intensive fishing activity (Fig. 1). As fishing effort rises to compensate for falling landings, previously unfished grounds begin to become the focus of attention. However, as effort falls, fishers largely return to their favoured localities (Fig. 2). Indeed, the proportion of seabed affected by fishing is highly predictable in line with fluctuations in total effort (Fig. 2). Faced with declining stocks and unrestricted fishing effort under a quota management system, fishers have the incentive to explore new grounds, thereby increasing their
Fig. 2. (a) Landings ( $\times 10^{4}$ tonnes) for International Council for the Exploration of the Sea (ICES) statistical area VIIa aggregated over three time periods, broken down into bottom-dwelling fish (solid bars), scallops (Pecten maximus, open bars) and Nephrops norvegicus (gray bars), which represent the target of the three main fleets that operate in these waters (data taken from Fishstat v. 2.3). While landings of scallops and Nephrops remained relatively constant across the three time periods, landings of fish (a proxy for fishing effort) declined concomitant with a contraction of areas of the sea affected by fishing effort in the third time period (1995-1999). (b) The change in the distribution of different intensities of overflight sightings is expressed as percent area of seabed for the 10 different categories of vessel sightings $(1=0.000-0.088 ; 10=0.79-1.121$ sightings per unit effort (SPUE)). 1995-1999, ○; 1990-1994, ם; 19851989, $\square$. (c) A plot of the difference in the change in distribution of sightings from the first to the second time period and from the second to the third time period. This strongly linear relationship indicates the predictability of the allocation of fishing effort in response to overall effort.

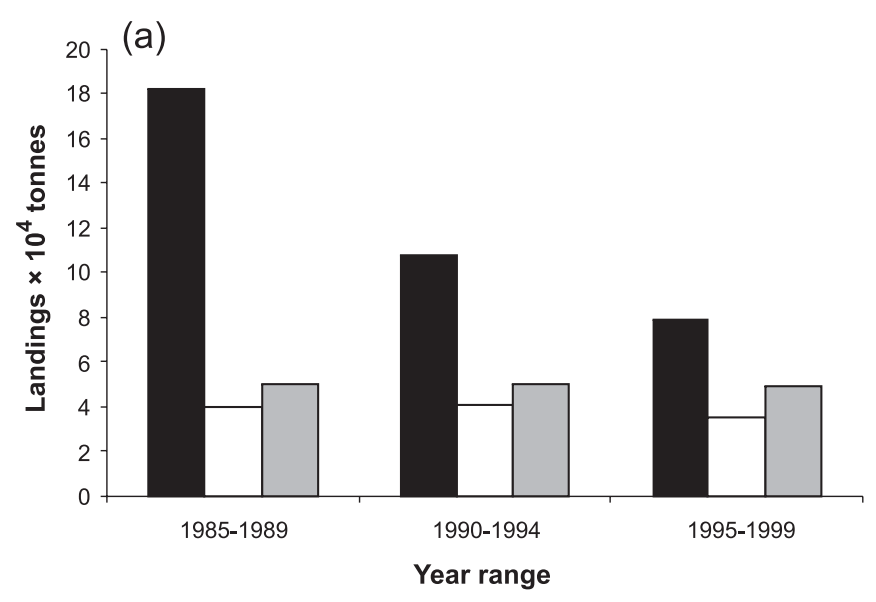

(b)

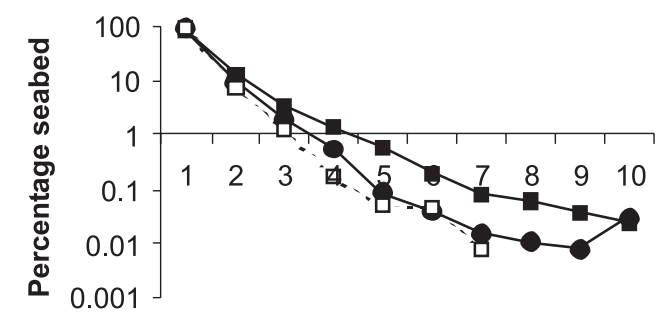

Sighting category

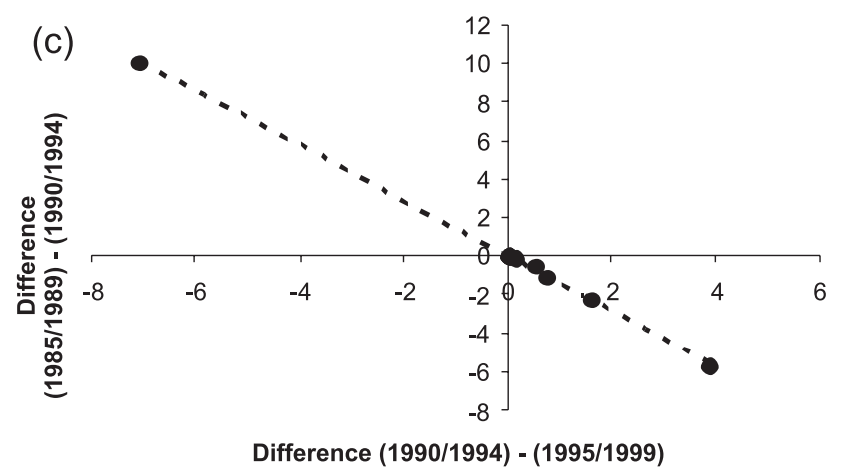


portfolio of knowledge and making it more likely that these grounds will be adversely affected in the future (Fig. 2b).

The aggregative behaviour of fishers has important ecological consequences, since the first few passages of bottomfishing gear across the seabed cause the biggest reduction in seabed community production and thereafter remains in a relatively constant condition of reduced benthic production (Jennings et al. 2001). It is important to appreciate that some fishers repeatedly fish the same tows several (or more) times per year on an annual basis. This aggregative behaviour occurs even over areas that have the same environmental conditions and hence the same potential benthic production in the absence of fishing (J. Hiddink, School of Ocean Sciences, University of Wales-Bangor, Menai Bridge, Anglesey LL59 5AB, UK, unpublished data). Thus restricting bottomfishing activities to confined areas of the seabed minimizes the spatial extent of the negative effects on seabed community production, which is a status that is already achieved as a result of fishers' behaviour and without the imposition of MPAs (Fig. 1). The imposition of MPAs without due consideration for fishers' behavioural responses may cause more damage than the status quo as evidenced by the recent "cod box" in the North Sea, which forced fishers to reallocate their effort to areas of the seabed where previously fishing boats had not been recorded (Dinmore et al. 2003).

The use of MPAs clearly has beneficial effects for very habitat-specific fish species associated with coral and temperate rock reefs, and they are the only tool that can effectively protect sensitive habitats such as beds of ancient calcareous algae and deep water corals (Willis et al. 2003b). In temperate waters, where the majority of the seabed is characterized by sediments and aggregates, sedentary species such as sea scallops and fish that have restricted movements are the most likely candidates to benefit from the exclusion of fishing activities (Horwood et al. 1998; Murawski et al. 2000). However, the scale of MPAs required to ensure sustainable fisheries of wide-ranging, long-lived species, such as cod and plaice, may be both impractical and equally prone to the same political horse-trading that has neutered many current management systems. New evidence suggests that in the worst case scenario, the ill-considered use of MPAs will displace fishing activity and thereby could result in additional damage to the marine environment before recolonization occurs in the newly protected area (Dinmore et al. 2003), whereas the proper implementation of fishing effort reduction still has the potential to out-perform the use of MPAs in terms of increasing spawning stock biomass (Steele and Beet 2003). As stocks recover and catch efficiency increases, the necessity to fish for prolonged periods and in marginal areas of the seabed should diminish. These beneficial effects of stock recovery can easily be undone by allowing the industry to expand uncontrolled, thereby exacerbating the "ratchet effect". In temperate systems, MPAs are not the singular solution to sustainable fisheries and are perhaps more a symptom of chronic failures to apply scientific advice (Hall 1999). Uncompromised management of fishing effort would simultaneously solve many of the wider negative, ecological, and socio-economic effects of overfishing.

If we are to advocate MPAs as a fundamental tool that can help to achieve sustainable use of marine resources, it is im- perative that the uncertainty regarding the outcome of such a management system is made clear to all stakeholders and that it is dependent upon adequate regulation and uncompromised implementation. In effect, any such shift towards the use of MPAs as part of our management tool portfolio should be tested using a rigorously designed, experimental management regime, the performance of which is tested in a scientifically objective manner and reviewed on a regular basis.

\section{Acknowledgments}

The author acknowledges financial support from the Marine Policy Center, Woods Hole Oceanographic Institute, and is grateful for the input of John Steele, Porter Hoagland, Di Jin, Nancy Shackell, and two anonymous referees. The views expressed in this article are those of the author alone and in no way reflect the views of affiliated institutions.

\section{References}

Agardy, T., Bridgewater, P., Crosby, M.P., Day, J., Dayton, P.K., Kenchington, R., Laffoley, D., McConney, P., Murray, P.A., Parks, J.E., and Peau, L.2003. Dangerous targets? Unresolved issues and ideological clashes around marine protected areas. Aquat. Conserv. Mar. Freshw. Ecosyst. 13: 353-367.

Blyth, R.E., Kaiser, M.J., Edwards-Jones, G., and Hart, P.J.B. 2002. Voluntary management in an inshore fishery has conservation benefits. Environ. Conserv. 29: 493-508.

Dinmore, T.A., Duplisea, D.E., Rackham, B.D., Maxwell, D.L., and Jennings, S. 2003. Impact of a large-scale area closure on patterns of fishing disturbance and the consequences for benthic communities. ICES J. Mar. Sci. 60: 371-380.

Frank, K.T., Shackell, N.L., and Simon, J.E. 2000. An evaluation of the Emerald/Western Bank juvenile haddock closed areas. ICES J. Mar. Sci. 57: 1023-1034.

Gell, F.R., and Roberts, C.M. 2003. Benefits beyond boundaries: the fishery effects of marine reserves. Trends Ecol. Evol. 18: 448-455.

Gillis, D.M., and Peterman, R.M. 1998. Implications of interference among fishing vessels and the ideal free distribution to the interpretation of CPUE. Can. J. Fish. Aquat. Sci. 55: 37-46.

Hall, S.J. 1999. The effects of fishing on marine ecosystems and communities. Blackwell Science, Oxford.

Halpern, B.S. 2003. The impact of marine reserves: Do reserves work and does reserve size matter? Ecol. Appl. 13: S117-S137.

Hart, P.J.B. 1998. Enlarging the shadow of the future: avoiding conflict and conserving fish off south Devon, U.K. Edited by T.J. Pitcher, P.J.B. Hart, and D. Pauly. Reinventing Fisheries Management, Kluwer, Dordrecht.

Hilborn, R., Stokes, T.K., Maguire, J.-J., Smith, A., Botsford, L.W., Mangel, M., Orensanz, J., Parma, A., Rice, J., Bell, J.D., Cochrane, K.L., Garcia, S., Hall, S.J., Kirkwood, G.P., Sainsbury, J.C., Stefansson, G., and Walters, C.J. 2004. When can marine reserves improve fisheries management? Ocean Coast. Manag. 47: 197-205.

Holland, D.S., and Sutinen, J.G. 2000. Location choice in New England trawl fisheries: old habits die hard. Landsc. Ecol. 76: 133-149.

Horwood, J.W. 2000. No-take zones: a management context. Edited by M.J. Kaiser and S.J. de Groot. The effects of fishing on non-target species and habitats: biological, social and economic issues. Blackwell Science, Oxford. 
Horwood, J.W., Nichols, J.H., and Milligan, S. 1998. Evaluation of closed areas for fish stock conservation. J. Appl. Ecol. 35: 893903.

Hutchings, J.A. 2000. Collapse and recovery of marine fishes. Nature (London), 406: 882-885.

Hutchings, J.A., and Myers, R.A. 1995. The North Atlantic Fisheries: successes, failures, and challenges. Edited by R. Amason and L. Felt. Institute of Island Studies, Charlottetown, P.E.I., Canada. pp. 38-93.

Jennings, S., Marshall, S.S., and Polunin, N.V.C. 1996. Seychelles' marine protected areas: comparative structure and status of reef fish communities. Biol. Conserv. 75: 201-209.

Jennings, S., Dinmore, T.A., Duplisea, D.E., Warr, K.J., and Lancaster, J.E. 2001. Trawling disturbance can modify benthic production processes. J. Anim. Ecol. 70: 459-475.

Jin, D., Kite-Powell, H.L., Thunberg, E., Solow, A.R., and Talley, W.K. 2002. A model of fishing vessel accident probability. J. Saf. Res. 33: 497-510.

Metcalfe, J.D., and Arnold, G.P. 1997. Tracking fish with electronic tags. Nature (London), 387: 665-666.

Murawski, S.A., Brown, R., Lai, H.-L., Rago, P.J., and Hendrickson, L. 2000. Large-scale closed areas as a fisherymanagement tool in temperate marine systems: the Georges Bank experiment. Bull. Mar. Sci. 66: 775-798.

Ray, G.C. 2004. Reconsidering "dangerous targets" for marine protected areas. Aquat. Conserv. Mar. Freshw. Ecosyst. 14: 211215.

Rijnsdorp, A.D., Buijs, A.M., Storbeck, F., and Visser, E. 1998. Micro-scale distribution of beam trawl effort in the southern North Sea between 1993 and 1996 in relation to the trawling frequency of the sea bed and the impact on benthic organisms. ICES J. Mar. Sci. 55: 403-419.
Roberts, C.M., Bohnsack, J.A., Gell, F.R., Hawkins, J., and Goodridge, R. 2001. Marine reserves enhance adjacent fisheries. Science (Washington, D.C.), 294: 1920-1923.

Roberts, C.M., Hawkins, J.P., and Gell, F.R. 2005. The role of marine reserves in achieving sustainable fisheries. Philos. Trans. R. Soc. Lond. B Biol. Sci., 360: 123-132

Russ, G., and Alcala, A. 1996. Marine reserves-rates and patterns of recovery and decline of large predatory fish. Ecol. Appl. 6: 947-961.

Sanchiro, J.N., and Wilen, J. E. 2001. A bioeconomics model of marine reserve creation. J. Environ. Econ. Manag. 42: 257-276.

Steele, D.H., and Beet, A.R. 2003. Marine protected areas in "nonlinear" ecosystems. Proc. R. Soc. Lond. B Biol. Sci. 270(Suppl.): S230-S233.

Steele, J.H., and Hoagland, P. 2003. Are fisheries "sustainable"? Fish. Res. 64: 1-3.

Steele, J.H., and Hoagland, P. 2004. Are fisheries "sustainable"? A counterpoint to Steele and Hoagland: a reply. Fish. Res. 67: 247-248.

Watling, L., and Norse, E.A. 1998. Disturbance of the seabed by mobile fishing gear: a comparison to forest clearcutting. Conserv. Biol. 12: 1180-1197.

Willis, T.J., Millar, R.B., Babcock, R.C., and Tolimieri, N. $2003 a$. Burdens of evidence and the benefits of marine reserves: putting Descartes before des horse? Environ. Conserv. 30: 97-103.

Willis, T.J., Millar, R.B., and Babcock, R.C. 2003b. Protection of exploited fishes in temperate regions: high density and biomass of snapper Pagurus auratus (Sparidae) in northern New Zealand marine reserves. J. Appl. Ecol. 40: 214-227.

Zeller, D., and Russ, G.R. 2004. Are fisheries "sustainable"? A counterpoint to Steele and Hoagland. Fish. Res. 67: 241-245. 